\title{
Eavesdropping and the Rule of Law. Constitutional and Criminal Aspect of this Phenomenon
}

\author{
Indrit Shtupi* \\ Arjan Vasjari \\ Xhabir Zejnuni \\ European University of Tirana \\ *Correspondng author: Cel: +355692926251/indritshtupi@yahoo.com
}

\section{Doi:10.5901/mjss.2013.v4n9p434}

Abstract

Eavesdropping is a means by which to achieve the detection of offenses and criminal offenses. It does not constitute a legal test as evidence not included in the legislation, but the tools to search for evidence. Such as tapping should be used when it detects these offenses which by their type is very difficult to detect. Of course, this means test does not need to reach the violation of fundamental constitutional rights in Albania since otherwise the test tool will become a mechanism for pressure and fear that people will unhappily booty of this tool.

Keywords: Eavesdropping, freedom of communication, human rights, international privacy, interceptions.

\section{Introduction}

1. Eavesdropping is nowadays a phenomenon that is spreading rapidly in the civil society of the 21 st century worldwide. Legal discussions that take place around this topic in Albania does not penetrate deep into the disbursement and legal justification of this action. Recent cases of interception and several judicial decisions pushed me to try to analyse this phenomenon purely legal elements, which unfortunately has been nuanced phenomenon dimensional (journalistic terms).

2. In this conference we presented primarily a legal term which contains communications interception itself as a legal phenomenon, which is sanctioning the freedom and privacy of correspondence in European and global level, to identify relevant articles in Albania, Albanian analysis of judicial decisions concerning on this issue recently and will give some decisions of the European Court of Human rights which constitute very important point in describing the interception as covered by this document.

\section{Communication. Its Types}

1. The condition of a very high importance to free movement and unrestricted is the principle of individual privacy and freedom of communication (Georgopoulos, J. (1991). pg. 57, Dhaktoglou, P. (2005). pg. 189). In this era of rapid development of telecommunications, broadcast messages under the thoroughfare secrecies constitutes a development of the personality of the citizen. Secrecies principle of inviolability of residence and, inviolability of private life, family, religious freedom, personal security and property rights are first and foremost, individual liberty, constitutional rights, which are enshrined in the Albanian Constitution of 1998 (Article 36 of the Constitution of the Republic of Albania). They formulate the limits of privacy protected by law through the provisions of the Constitution and the Penal Code (Articles 221-222 of the Code of Criminal Procedure of the Republic of Albania). The principle of confidentiality of correspondence has two separate components: first, freedom of communication or correspondence with official documents and in any other way, secondly, the confidentiality of all forms of communication, when they want to communicate love to secrecy. If someone wants to communicate not kept secret, we have no occasion of confidentiality of correspondence but freedom of speech (Karas, A. (1996). pg. 34, Katrougkalos, J. (2001). pg. 59, Manesis, A. (1982). pg. 234, Spinelis Dh. (2004). pg. 86). 
2. Everyone question naturally arises. Communication in a legal contest by definition what is? A definition of communication can be summarized as follows: Communication is human activity through which a person comes into contact, cooperate with others. Communications are of two types. A first type is that of personal direct, and a second type is the cross-correlates. A direct communication is direct contact of people communicate, so individuals are physically present during the communication. In indirect communication with persons are far from each other, making it impossible for their physical contact. As a result of their distance individuals use several means of communication, such as email phone, fax, etc.. After an analysis of the definition and validation of communication seen to be fair in the European and international level.

\section{European and international constitutions}

1. Inviolability of correspondence is published by the French Constituent Assembly in its resolution dated August 10, 1789. In the Declaration of the Rights of Man and Citizen had no confidentiality protection and the same approach followed the French constitutions of 1791, 1793 and 1795. In the United States privacy protection sanctioned by the Fourth Amendment to the Constitution in 1791 (folded and secrecy of correspondence). The Belgian Constitution in 1831 had a provision (Article 22), which sanctioned the principle of inviolability of the confidentiality of documents. Nowadays Belgian Constitution of 1994 and in particular Article 29 provides for the confidentiality of correspondence and communication: "The confidentiality of documents is inviolable. Law determines which bodies are responsible for violating the confidentiality of documents that someone has trusted mail. For Furthermore, Article 18 paragraph 3 of the Spanish Constitution of 1978 states: "It is guaranteed confidentiality of responses, especially post, telegraph and telephone communications, unless there is a court decision. Article 23 paragraph 2 of the Russian Federal Constitution of 1993 states that: "Everyone has the right to privacy of telephone communications and postal correspondence, telegraph and other. Limitation of this right is not permitted, except by judicial decision.

2. Article 34 of the Bulgarian Constitution of 1991 provides: "The freedom and privacy of correspondence and other communications should be inviolable". Section 9A Greek Constitution states that "Everyone has the right to protection from the collection, processing and use, especially by electronic means, of personal data laid down by law. Protection of personal data provided by an independent authority established and operating as defined by law ". Article 19 of the Greek Constitution states that "Paragraph 1. Confidentiality of documents, correspondence and communication with free otherwise absolutely inviolable. The law provides guarantees under which judicial authorities are not dependent on the secrecy of correspondence. These reasons are: 1. For reasons of national security or 2. For the detection of particularly serious crimes. Paragraph 3 . The use of evidence obtained in violation of this section and section 9A. Article 10 of the German Constitution states that "1. Confidentiality of documents and mail documents and communications are inviolable to 2. Are permitted only by law. If restrictions designed to protect the legal order or security of the Federation or of the country, the law cannot assign notification to the concerned authorities and instead penetrate judicial bodies authorized representative of the people or entities sourcing. In the French Constitution, there is no specific provision for ad hoc communications to ensure confidentiality (Kaminis, J. (1995). Journal 43, Kaminis, J. (2001). pg. 87). However, according to the French doctrine and jurisprudence, this right derives from Article 8 of the ECHR and Article 11 of the Declaration of 1789 ("the free communication of thoughts and opinions is one of the most precious rights of man. Every citizen may speak, write and to publish free, without excluding the possibility that he disclose the abuse of this right in cases defined by law), which has the constitutional power (within the socalled bloc de constitutionnalite). Article 15 of the Italian Constitution sets that "freedom and privacy of communication and any other means of communication are sacred and inviolable." Limit allowed only with the written act of judicial authority under the guarantees provided for in law. Irish Constitution does not sanction a separate article for this right.

\section{Europeans sanctioning international privacy and freedom of correspondence}

\subsection{Article 8. European Convention on Human Rights}

Secrecy of communication is involved in almost all-European international human rights Conventions.

1. Everyone faces the historic right to respect for private life and family life, home and his correspondence. 
2. A public swimming Authority damn INTERFER with the Exercise of this right is in. Except Such as ACCORDANC with the law and is Necessary in a Democratic Society, in the Interests of public safety, for the Protection of public order, health or morals or for the Protection of rights and freedoms of others.

\subsection{Article 10. Freedom of expression}

1. Everyone has the right to freedom of expression. This right includes freedom to hold opinions and freedom to receive and impart information and ideas without interference by public authority and regardless of frontiers. This article shall not prevent States from requiring the licensing of broadcasting enterprises, television or cinema.

2. The exercise of these freedoms, since it carries with it duties and responsibilities, may be subject to such formalities, conditions, restrictions or penalties as are prescribed by law and are necessary in a democratic society in the interests of national security, territorial integrity or public safety, for protection order and prevention of crime, for the protection of health or morals, for the protection of the reputation or rights of others, for preventing the disclosure of confidential information or for maintaining the authority and impartiality of the judiciary.

\subsection{Article 12. Universal Declaration of Human Rights}

1. No one shall be subjected to arbitrary interference with his privacy, family, home or correspondence, nor to attacks upon his honour and reputation.

2. Everyone has the right to the protection of the law against such interference or attacks.

\subsection{Article 17. International Covenant on Civil and Political Rights}

1. No one should be the object of arbitrary or unlawful intervention in the life of his privacy, in family, home or correspondence, nor should violate his honour and reputation in the illegal way.

2. Everyone has the right be no legal protection against such intervention and violations of.

\section{Interceptions in Albania}

1. Interceptions in Albania have known a great spondents, and this of course is due to the fact that the democratic society in which we live requires recording and verification of criminal offenses or offenses committed within the territory of Albania. Interceptions in their nature usually seek the persons and public disclosure of corruption affairs in which senior officials participating state (Ciris, P. (2002). pg. 234, Hrisogonos, K. (2002). pg. 89). Albanian Criminal Code reflects in detail how the procedure and develop a peek in our country and in turn the fundamental law of the state in Article 35 paragraph 2 (collection and disclosure of information about a person is done with his consent, except provided for in law), Article 36 (which clearly defines the principle of confidentiality of correspondence and personal data of persons) and 32 (second paragraph under which no one can be declared guilty on the basis of data collected illegal).

2. For our personal opinion on the legal provisions of the Constitution of Albania need to supplement concerning interception. While criminal law is so comprehensive as it provides extensive and analytical conditions and how they develop a peek Albanian Constitution in this regard is poor legally leaving open many windows which can lead us to wrong decisions as happened with the Albanian courts that their decisions have dealt with legal language bilingual (will analyse these decisions below), which causes a legal unevenness in our state. Relevant articles of the Criminal Code sections 221-226, which are regulated by Law no. 9187/2004. At this point it is best to look legal opinion of some Albanian lawyers who analyse the issue of evidence and tools used in a surveillance could be considered as evidence and also referring to the relevant sections of the Code of Criminal Procedure. Proof prohibited in criminal or civil proceedings should be considered those who oppose prohibitive or mandatory rules of law, particularly when they violate individual rights guaranteed in the Constitution, and there is no other rule of law that legally justify this violation (Dimitropoulos, A. (2005). pg. 345, lliopoulou \& Strang J. (2003).pg. 125). The conclusion of the preceding objection to a proof of sufficient labelled illegal (Kesis, Thanas. (1986). pg. 26). According to the Albanian criminal procedural legislation, when 
it comes to evidence, we have, among others, two major parts: First we have: I-types of evidence, which includes 1) Testimony 2) The question of the defendant and the private parties; 3) dealings; 4) Recognition; 5) Surveying and 6) experiment, and II-search tools to test, including: 1) scan; 2) Controls 3) Seizures and 4) Interception of conversations or communications (Lawyer Igli Totozani (Professor of Public Law) Http://www.shekulli.com.al/).

3. So, from the above, the theory and practice of criminal proceedings, tapping recognized as one of the research means test. As a tool for research evidence, is tapping two kinds: interception of telephone conversations or communications, and other forms of communication and environmental tapping, which is realized through listening and recording audio and video with special devices that are placed in different environments or in certain persons. Tapping that takes place in a private environment (office, home, restaurant between two friends, two public persons) is a privately conducted environmental interceptions which means the audio and video recording without a court order. We note that tapping the Code of Criminal Procedure allowed only for certain categories of offenses or lawlessness (Article 221 of Code of Criminal Procedure of the Republic of Albania), and always with the decision of the Court (Judge) at the request of the prosecutor or the "urgent cases" the prosecutor himself who within 24 hours must notify the court and require that validation of the act (Article 222 of Code of Criminal Procedure of the Republic of Albania). Commentary on the Criminal Procedure find: "Taped done privately and cannot be used as evidence, but they can serve as a reason for initiating criminal proceedings mainly by the prosecutor, who is obliged to verify the alleged fact, taking any necessary test (Islami, H., Hoxha, A., Panda, I., (2007). pg. 286).

4. This assertion of this commentary gives us the Constitution which clearly and in its Article 148 provides that attorney is a constitutional body that exercises criminal prosecution. This constitutional body has the right and obligation to exercise legal prosecution, through legally defined ways (http://www.shekulli.com.al). In the context of the exercise of prosecution among modes are legally start of criminal proceedings or charges through his own initiative and with the prosecution under Section 280 of the Code of Criminal Procedure. The burden of proof under the rules of procedure belongs to the prosecution. Evidence under section 149 of the Penal Procedure Code, obtained from sources provided in procedural law, and in accordance with the rules laid down by him. According to the lawyer Agron Bajric tapping itself is not proof but the proof search tool that is regulated by Articles 221 and following of the Code of Penal Procedure. Case tapping carried out in secret and by entities not entitled to exercise the prosecution case procedurally interpreted as where the results obtained by tapping can be used to initiate prosecution by the prosecution as stated above. These results whatever they may be, must be verified for the purpose of determining their authenticity, and the prove effect which can be achieved only in the case where the interception is based on evidence.

5. Under our procedural law, not allowed to collect the evidence made by other entities, which are defined as entities that carry out criminal prosecution. Under Article 151 of the Penal Procedure Code stipulates that evidence taken from the body during the initial investigation and proceed to trial evidence obtained upon request from the Court. In this context, tapping carried out by private entities cannot constitute proof, but only due to the commencement of prosecution by the prosecution. While our legislation does not allow investigation of private entities, opening the way for the use of surveillance conducted by entities for personal or other reasons, constitutes a precedent would be distasteful and ineffective for our justice system and taking into account Article 32/2 of the Constitution the RA's which states that no one may plead guilty on the basis of data collected illegally. By analysing the opinions of two prominent lawyers in Bangladesh who are pros use of surveillance as a test tool for legal reasons analysed above should be seen and the opinions of other lawyers who oppose the tapping tool can be used as evidence in court. Such a legal opinion supported by Mr. Visha sajmir who also holds the post of President of Albania lawyers panellists. Mr. Legal opinion. Visha interceptions which is not conducted in conformity with the procedure prescribed in the aforementioned articles of the Criminal Procedure Code are illegal. Footage and voice broadcast of a tape not constitute material evidence, but no means to validate the test, as this test is taken in violation of the clear and the articles of the Code of Criminal Procedure. Code of Criminal Procedure emphatically describes the relevant legal procedure and in case of such an issue then when we use a form of surveillance tape in court should not consider these tapes after missing the fact criminal.

6. Conclusion: From the above analysis it appears that there are two legal opinions for the use of electricity as a means of tapping the admissibility of his evidence. The first thought which equates tapping test as a tool to initiate an investigation by the Prosecutorial more accepted by my side, because the role of the prosecution is 
a criminal always proceed according trails of this organ in the investigation of the charges . In the case of a video of the prosecution office (liability given by Article 148 of the Constitution) is to verify the authenticity of the surveillance and if we committing a criminal offense under the procedure provided proceed. Im am personally agree with the second legal opinion which states against the use of surveillance as a means of tapping test as it is not conducted in conformity with the relevant provisions of the Code of Criminal Procedure. Legally defend the idea that in the case of the Albanian justice authenticity of communications has only benefits and no loss or violation of constitutional rights.

\section{Albanian court decisions. "Justice double standards"}

1. Case 1. In early 2008, we have a decision of the Court of First Instance in the capital which has described the decision illegal and against the law wiretaps former Director General of Police, Prisons, had performed in his office during Rusmajli conversation with Edmond citizen. Following the publication of this video, prosecutors began investigating after being fired after the Court had invalidated surveillance conducted by former police director. Based on this decision, prosecutors closed the criminal proceeding. The court ruled that in this case did not apply the legal procedure provided for in article 222 of the Code of Criminal Procedure for the development of surveillance by the competent authority as a result of surveillance crash test tool to initiate preliminary investigations for the offense.

2. Case 2. But in 2008 we have a second chance in the same way and tapping footage, perform the office of a former prosecutor from a national program with the help of "Fixed-fare", where the prosecutor demanded a sum of money from a father detainee, to obtain a more lenient sentence measure and Kavajes Court has recognized as material evidence (http: // www. shekulli. com.al). Based on this surveillance, which appear prosecutor counting money and filmed by the father of the defendant, black platoons have considered lawful interception by sending suspended from duty prosecutor on trial for charges of passive bribery of persons exercising public functions.

3. Case 3. In 2010 we presented a video which was recorded at the home of a minister who was invited to his house a girl who is looking for a job. Tirana Court after reviewing the materials submitted by the parties decided to punish the party had conducted surveillance tool-proof as it was done against the law to violate several articles of the Albanian Constitution and the European Convention of Human Rights (The case Von Hanover versus Germany 2004) (Article 37 of the Constitution of Albania which provides for the inviolability of the dwelling, Article 15 of the Constitution which states that constitutional rights are inviolable, Article 35 of the Constitution, second paragraph, which states that the collection, use and disclosure of information about a person done with his consent, except in cases provided by law and the articles of the ECHR 8.10, 41 the right of residence, family, and integrity of their correspondence). According to the plaintiff, audio-visual recordings carried and transmitted by the defendant realized from it in defiance of the Albanian legislation in force (Criminal Procedure Code).

4. Conclusion: By analysing the above decisions of the courts of first instance conclude that the path followed by their legal double standard is because in the first and third court does not consider interception-proof tool while in the second case considering tapping as evidence by bringing legal consequences mentioned above. This solution is dangerous in a legal state after the court's role is to unify her thoughts in the form of judgments, not legal bilingualism which causes legal uncertainty which they have a role to sanction in Bangladesh and around the world

\section{The decisions of the Strasbourg Court}

1. The issue of P.G and J.H. v. the United Kingdom (Request nr.44787/98, 25 September 2001, ECHR). In this case the court found a violation of Article 8 of the Convention because the police had used the listener, which was not authorized by a special legal framework. If the measure constitutes an interference with the rights provided for in Article 8 and there is no clear authority for this measure under national law, in such a case is automatically in violation of the Convention. So, it would be trivial pursuit of a legitimate aim, such as crime prevention and investigation. In relation to Article 13 of the Convention, the Court noted that the domestic courts had not been able to provide an effective tool in itself because it did not evaluate the intervention appeal to the right of the applicants to respect for private rights of researchers, which was not in accordance 
with law, nor had given the necessary attention in the context of the appeal process. The Court found that the complaint investigation system does not meet the independence standards required to make a sufficient protection against abuses of authority by presenting an effective tool in the sense of Article 13 of the Convention. It concluded that a violation of this article.

2. A very interesting case is reviewed by the ECHR is the issue Klass and Others v. Germany 09.06.1978 (Request nr.5029/71, September 6, 1978). This is a decision for tapping to prevent crimes against the internal security and external in Germany. Five German nationals former West Germany fell victim to claim that German state surveillance carried out for internal security. In June 1971 the applicant submitted a request to the European Commission of Human Rights, alleging that the German legislation violated the Convention in Articles 8 and 13. In this case the Court dealt first with the issue of interception of postal and telephone communications. The Court acknowledged that the German legislation which allowed the interception of postal communications and control for public safety purposes, was compatible with Article 8 of the Convention. She managed to justify this legislation, arguing that it was necessary in a democratic society in the interests of national security and the prevention of disorder. The Court states in its decision that the monitoring of telephone calls within the scope of the right to privacy can only be done when there is strong evidence against persons who commit or prepare to commit serious crimes.

3. Decisions of 04.24.1990 Kruslin and Huring "Interception of telephone calls by the courts." The problem that arises is that compatibility-compliance may be tapping with Article 8 of the Convention when tapping case of a suspect by the land-based investigation of French law in force that allows this to peek inside his reasons analysed. This law is accompanied by appropriate safeguards which determine the manner and consequences of interception. ECtHR held that "the interception of telephone conversations constitute a serious violation of privacy rights of any person." Intercepts should therefore be based on a law whose provisions are very "clear, detailed and frank." The Court notes that the law should be "approachable for the average citizen" and to "the possibility of predictability." The court decided after examining the law that the French legislation does not provide sufficient security for citizens with the result that "17 guarantees" provided by this law are considered insufficient by the ECHR. The Court concluded that French law does not provide exactly the criteria that should guide the discretion of the decision to violate the principle of free communication. Therefore, the applicant Kruslin who was sentenced by the court France did not enjoy a minimum level of protection required which is required by the rule of law in a democratic society ". Court decided the following conditions: The law shall determine the categories of persons whose phone conversations can be intercepted, the nature of crime investigation which requires a violation of the principle of correspondence. Law should also provide for the authority to decide on the interception and the maximum time that will last interception.

4. Contreras.v.Spain. Court appointed as conditions:

a) determining the category of persons to whom their conversations can be intercepted,

b) determine the time of receipt of the decision to intercept.

c) setting a deadline for the measure

d) Minutes for the design and content of communications

e) determining the time and manner of destruction of documents.

Regarding clause contained in the ECHR "the necessity of the measure in a democratic society to achieve a legitimate objective" required in the performance of their surveillance enclosed by a legal framework guarantees, which will ensure that this is carried out in border surveillance necessary to achieve the goal and the rights of the person affected will be protected. Basic Warranty body set up primarily for surveillance and guarantees a fair development and its legal and judicial protection secondly has the right to demand affected by tapping.

5. Kruslin and Huvig against France. The court called for the law to determine how surveillance should be determined by which they guarantee to ensure that intercepted telephone communications will be recorded and will reflect the whole.

\section{Conclusion}

From the above analysis it appears that tapping is a test tool which recognizes nowadays widely used for the certification of corrupt phenomena of society in which we live. Legal problem that arises is his heath as evidence when the 
surveillance is not conducted by the competent authorities and the ways contemplated in the relevant criminal law. After presenting some legal opinions of lawyers and law professor's conclusion was reached in which the tapping should be taken as a proof as it equates to a criminal charge and it is the duty of prosecutors, to verify its authenticity. Tapping in itself does not constitute a legal test, but a means to achieve the test results in its use to reflect the authenticity of the phenomena that occur in modern democratic society in which we live.

\section{References}

Georgopoulos, J. (1991). "Constitutional Law".

Dhaktoglou, P. (2005). "Constitutional Rights".

Constitution of the Republic of Albania.

Code of Criminal Procedure of the Republic of Albania.

Karas, A. (1996). "The Criminal Law of Procedure", Athens-Komotini.

Katrougkalos, J. (2001)."Review of classical rights and guarantees", Athens Komotini.

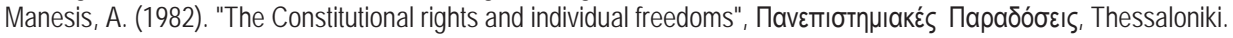

Spinelis Dh. (2004)."Prohibition of evidence in a criminal trial", legal journal.

Kaminis, J. (1995). "Privacy of telephone communication": the constitutional protection and its application by the penal lawmaker and courts, NoB Law Journal 43.

Kaminis, J. (2001). "Tools and sanctioning illegal constitutional test of constitutional rights. Proved prohibitions in a criminal and civil trial", Athens, Komotini.

Ciris, P. (2002). "Sanctioning constitutional right to privacy of communication", Athens-Komotini.

Hrisogonos, K. (2002)."The individual and social rights", the second volume.

Dimitropoulos, A. (2005). "Constitutional Law", Special Part, the third volume, Athens.

lliopoulou \& Strang J. (2003)."The use of illegal evidence and the right of defence of the accused", Athens-Komotini.

Kesis, Thanas. (1986). "lllegal legal tools", Thessaloniki.

Islami, H., Hoxha, A., Panda, l., (2007)."Commentary of the Code of Criminal Procedure", Tirana.

The case Von Hanover versus Germany 2004.

Request nr.44787/98, 25 September 2001, ECHR.

\section{Internet Sources}

Lawyer Igli Totozani (Professor of Public Law) Http://www.shekulli.com.al/

http://www.shekulli.com.al 